\title{
Czarownica w literaturze polskiego oświecenia Stereotyp i płeć
}

Czarownicy - ludzie, którzy dzięki paktowi z diabłem dokonują rzeczy nadprzyrodzonych z pomocą sił piekielnych. W rzeczywistości to najczęściej oszuści, szarlatani, łotrzykowie, maniacy, wariaci, hipochondrycy i inni nicponie, którzy nie mogąc dodać sobie powagi zasługami, osiągali to starając się wzbudzić lęk.

J. Collin de Plancy, Słownik wiedzy tajemnej ${ }^{1}$

Modelowe wizerunki czarownic wizualnie oscylują między dwoma przeciwieństwami: brzydkiej staruchy i pięknej dziewczyny. Schematyczne i wyraziste, szybko utrwaliły się w wyobraźni społeczeństwa. Jeśli chodzi o mężczyzn, proponowano szlachetniejsze i bardziej urozmaicone wzorce. Wiąże się to $\mathrm{z}$ wieloma czynnikami, między innymi z początkami kształtowania się paradygmatu czarownicy. Ustalał się on latami, na gruncie demonologii chrześcijańskiej, tradycji literackiej i reliktów dawnych wierzeń.

Celem artykułu jest próba wyjaśnienia, czy rola i funkcja czarownicy w piśmiennictwie dawnym warunkowana jest jej płcią i przekonaniem, że skłonności do czarów wiążą się z funkcjami biologicznymi kobiety. Postaram się także ustalić, jak na stworzony w XVI wieku stereotyp wiedźmy wpłynęła zmiana relacji między płciami w XVIII stuleciu.

Zaprezentowanie wizerunku czarownicy w dawnej Europie nie jest zadaniem łatwym, podobnie jak opisanie czarownictwa. Mamy do czynienia z zagadnieniem bardzo szerokim i powiązanym z szeregiem zjawisk pokrewnych. Czarownicami zajmują się reprezentanci różnych dziedzin i dyscyplin akademickich, czego pokłosiem są publikacje o charakterze naukowym oraz ujęcia popularne, przeznaczone nierzadko dla czytelnika spragnionego sensacji i krwawych histo-

${ }^{*}$ Dr hab. prof. UMK, Uniwersytet Mikołaja Kopernika, Wydział Filologiczny, Zakład Literatury Oświecenia, ul. Fosa Staromiejska 3,87-100 Toruń; e-mail: jurans@umk.pl

${ }^{1}$ J. Collin de Plancy, Czarownicy, w: Stownik wiedzy tajemnej, wybór i przekład M. Karpowicz, Oficyna Wydawnicza Polczek, Warszawa-Kraków 1993, s. 38. 
rii $^{2}$. Znaczny wzrost zainteresowania tematem datuje się na lata siedemdziesiąte XX wieku, głównie za zachodzie Europy. Zjawiska magiczno-demoniczne nadal inspirują do dyskusji na konferencjach i sesjach naukowych, zwykle interdyscyplinarnych ${ }^{3}$. W najnowszych książkach bardzo wyraźnie zaznaczają się tendencje komparatystyczne.

Wciąż jednak znajdujemy obszary, które wymagają dopełnienia i dookreślenia. Wątpliwości budzi geneza polowań ${ }^{4}$, przyczyny ich wygaszenia ${ }^{5}$ oraz liczba ofiar (szacowane liczby to od 40 tys. ofiar obojga płci do $9 \mathrm{mln}$ kobiet). Od kilku lat obserwujemy tendencję do obniżania szacunkowej ogólnej liczby ofiar, nieraz znacząco zawyżanych. Obecnie historycy podają, że w wyniku procesów o czary stracono w Europie około 50 tysięcy osób ${ }^{6}$.

${ }^{2} \mathrm{~W}$ ostatnich dziesięciu latach opublikowano m.in. następujące rozprawy: J. Wijaczka, Procesy o czary w Prusach Ksiażęcych (Brandenburskich) w XVI-XVIII wieku, Wydawnictwo Naukowe Uniwersytetu Mikołaja Kopernika, Torun 2007; tenże, Magia i czary. Polowanie na czarownice i czarowników w Prusach Ksiązęcych $w$ czasach wczesnonowożytnych, Wydawnictwo Adam Marszałek, Torun 2008; M. Pilaszek, Procesy o czary w Polsce w wiekach XV-XVIII, Universitas, Kraków 2008; D. Kowalewska, Magia i astrologia w literaturze polskiego oświecenia, Wydawnictwo Naukowe Uniwersytetu Mikołaja Kopernika, Toruń 2009; P. Rutkowski, Kot czarownicy. Demon osobisty w Anglii wczesnonowożytnej, Universitas, Kraków 2012; B. Marcińczak, „Między tacnowiernościa i niewiernościa”. Diabet magia i czary w „Nowych Atenach” $i$ „Diable w swojej postaci”, Wydawnictwo DiG, Warszawa 2014. Warto też odnotować pierwszą monografię procesów o czary w Polsce, wydaną w języku angielskim: W. Wyporska, Witchcraft in Early Modern Poland, 1500-1800, Palgrave Macmillan, Basingstoke 2013. Autorka wprowadza do międzynarodowego dyskursu o czarach nie tylko najnowsze ustalenia polskiej historiografii, ale i nieznane dotąd szerzej prace staropolskich i oświeceniowych demonologów.

${ }^{3}$ Zob. Zjawiska magiczno-demoniczne na terenie dawnych ziem pruskich na tle porównawczym, red. K. Grążawski i J. Gancewski, Wydawnictwo Uniwersytetu Warmińsko-Mazurskiego, Olsztyn 2015; Czary, alchemia, opętanie w kulturze na przestrzeni stuleci. Studia przypadków, red. J. Pietrzak-Thebault i Ł. Cybulski, Wydawnictwo Uniwersytetu Stefana Kardynała Wyszyńskiego, Warszawa 2015.

${ }^{4}$ Już w starożytnej Grecji zapadały wyroki śmierci za czary, jednak dopiero w czasach chrześcijańskich cesarzy w IV i V w. represje nasiliły się w niespotykany sposób. Zob. A. Wypustek, Magia antyczna, Zakład Narodowy im. Ossolińskich, Wrocław 2001, s. 337. Polowania na czarownice na masową skalę rozpoczęły się w Europie w końcu XVI w., kiedy to połączyły się w jedno różne funkcjonujące dotąd osobno wyobrażenia.

${ }^{5}$ Autorzy najnowszych badań, również polskich (M. Pilaszek, dz. cyt.; B. Marcińczak, dz. cyt.), wiążą kres prześladowań z wieloma czynnikami, na przykład z pojawieniem się nowej konkurencyjnej koncepcji natury i utratą wiary w realność czarów.

${ }^{6}$ Połowa egzekucji została wykonana na obszarze Rzeszy Niemieckiej. B. P. Levack w trzecim wydaniu swojej monografii zdecydował się obniżyć liczbę procesów i egzekucji, pomimo że wcześniej był krytykowany za ostrożność w szacowaniu liczby ofiar. Zob. tenże, Polowanie na czarownice w Europie wczesnonowożytnej, przeł. E. Rutkowski, z dodatkiem Katalogu magii Mnicha Rudolfa zabytku z XIII w. w przekładzie E. Karwota, Zakład Narodowy im. Ossolińskich, Wrocław 2009, s. 10, 35-40. 
Nieprawdziwe okazały się również liczby podawane przez Bohdana Baranowskiego ${ }^{7}$, autora publikowanych w latach pięćdziesiątych i sześćdziesiątych poczytnych książek o czarach, współcześnie krytykowanego za ideologizację badań Ciekawie prezentuje się kwestia dysproporcji między ilością oskarżanych kobiet i mężczyzn $(75 \% \text { i } 25 \%)^{8}$, podnoszona w badaniach nad czarownictwem wielokrotnie, zwłaszcza w interpretacjach feministycznych ${ }^{9}$. Niepokój badawczy wywołują też początki kształtowania się literackiego obrazu czarownicy oraz jego ewolucja.

W opisie zjawiska pojawiają się paralelne informacje. Nic dziwnego, bo autorzy korzystają z tych samych źródeł, zwłaszcza kanonu literatury demonologicznej, zawierającego założenia wczesnonowożytnej teorii czarownictwa. Należy do niego osławiony Młot na czarownice Heinricha Krämera ${ }^{10}$ oraz dzieła takich autorów jak: Jan Nider, Ulrich Molitor, Jean Bodin, Henri Boguet, Pierre de Lancre czy Martin Del Rio. Literatura ta odbija, kreuje i podtrzymuje ówczesną magiczną wizję świata. Prześledzenie debaty dotyczącej czarownic, która toczyła się głównie w Europie zachodniej, pozwala zrozumieć przemiany, jakim ulegał wizerunek czarownicy od późnego średniowiecza do romantycznego przełomu oraz uchwycić swoistość rodzimych procesów.

Współcześni badacze zazwyczaj deklarują, że chcą ,,dokonać weryfikacji rozmaitych półprawd i stereotypów, utrwalanych w wielu wciąż bezkrytycznie przytaczanych pracach naukowych"11. Zdarza się, że nie tylko podważają ustalenia swoich poprzedników, ale i kwestionują zasadność korzystania z wybranych metod czy narzędzi badawczych. Zastrzeżenia rodzimych badaczy do ujęć komparatystycznych wynikają z przekonania, że autorzy obcojęzyczni nie znają polskich archiwów, a ich ustalenia odnoszą się do odmiennych warunków.

Choć stopniowo eliminuje się , ,historyczne fałsze”, które stwarzają mylny obraz czarownictwa w Europie ${ }^{12}$, do dziś pozostaje ono fenomenem złożonym, wie-

${ }^{7}$ Procesy czarownic w Polsce XVII i XVIII w., Łódzkie Towarzystwo Naukowe, Łódź 1952; O hultajach, wiedźmach $i$ wszetecznicach, Wydawnictwo Łódzkie, Łódź 1963; Pożegnanie z diabłem i czarownica, Wydawnictwo Łódzkie, Łódź 1965.

${ }^{8} \mathrm{Jak}$ pokazały najnowsze badania, proporcje zmieniają się w zależności od miejsca zamieszkania oskarżonych. Por. B. P. Levack, dz. cyt., s. 187-188.

${ }^{9}$ Zob. G. Bechtel, Cztery kobiety Boga: ladacznica, czarownica, święta, głupia gesś, przeł. K. Pachniak, Wydawnictwo Akademickie Dialog, Warszawa 2001; D. Gilmore, Mizoginia, czyli męska choroba, przeł. J. Margański, Wydawnictwo Literackie, Kraków 2003; Czarownice, w: W. Kopaliński, Encyklopedia „,drugiej ptci”: wszystko o kobietach, Rytm, Warszawa 2006, s. 601.

${ }^{10}$ Autorem dzieła był tylko Krämer, który dopisał jako współautora Jakuba Sprengera, aby dodać dziełu powagi. Zob. P. Segl, Heinrich Institoris. Persönlichkeit und literarisches Werk, w: Der Hexenhammer. Entstehung und Umfeld des Malleus maleficarum von 1487, red. P. Segl, Böhlau, Köln-Wien 1988, s. 103-126.

${ }^{11}$ B. Marcińczak, dz. cyt., s. 4 okładki.

${ }^{12} \mathrm{Na}$ gruncie polskim m.in. dzięki pracom Janusza Tazbira i Jerzego Michalskiego. Zob. J. Tazbir, Wawrzeniecki i Żagiell jako twórcy falsyfikatów, „Nauka” 3 (2006), s. 45-53; J. Michal- 
lowymiarowym i opierającym się jednoznacznym interpretacjom. W badaniach ujawniły się różne postawy (racjonalistyczna i romantyczna, kojarzona głównie z Julesem Micheletem) i modele postępowania (,model wyznań i oskarżeń”, „model centrum i peryferii" ${ }^{13}$. Czarownica postrzegana jest jako służka szatana, kozioł ofiarny, wytwór patriarchalnego świata, relikt starożytnej religii płodności czy antyteza idealizowanej dziewicy Marii.

Przekonanie, że w dawnej Europie czary uprawiały wyłącznie łatwiej ulegające emocjom kobiety, jest jednym z uproszczeń, pojawiających się w obiegowych opiniach o czarownicach. Przeczą temu nie tylko statystyki, ale i lektura wczesnonowożytnych traktatów demonologicznych. Mimo to stereotyp jest tak silny, że wielu ludzi wyraża dziś zdziwienie, że o czary oskarżano również mężczyzn. Co prawda chrześcijańscy moraliści widzieli w kobietach istoty szczególnie podatne na magię i zabobon wskutek ich rzekomej słabości moralnej i umysłowej, ale nie widzieli powodów, żeby z kręgu podejrzanych całkowicie wykluczyć mężczyzn $^{14}$. Dlatego, choć w dużo mniejszym stopniu, oni również byli przesłuchiwani i skazywani. W krajach katolickich wśród straconych było około $30 \%$ mężczyzn, w protestanckich - zaledwie 10\%. Im dalej na wschód, tym proporcje są bardziej odwrócone. W Rosji mężczyźni stanowili nawet do 90\% obwinionych, podobnie jak w Estonii czy Finlandii ${ }^{15}$. Być może wiązało się to $\mathrm{z}$ wyodrębnieniem typowo męskich i żeńskich dziedzin magii. Kobiety dominowały w obszarze magii związanej z narodzinami, śmiercią, erotyką i prokreacją oraz we wróżbiarstwie. Mężczyźni zapewniali urodzaj i powodzenie w gospodarstwie oraz bezpieczeństwo grupy. W Rosji prawdopodobnie to czarownicy leczyli impotencję i zajmowali się czarami wojskowymi, o czym świadczy wprowadzenie w 1716 roku przez Piotra Wielkiego prawa skierowanego przeciw takim czarom $^{16}$.

W wielu językach brakuje nazw dla mężczyzn parających się czarami, a jeśli się pojawiają, to jest ich mniej i - w przeciwieństwie do żeńskich - nabierają konotacji dodatnich ${ }^{17}$. Również w dawnej polszczyźnie żeńska nomenklatura magiczna jest bardziej urozmaicona ${ }^{18}$. Powszechnie znane określenia, takie jak ,czarownica”, „wiedźma”, „baba” czy „wróżka”, dają wyobrażenie o kompetencjach

ski, Jeszcze o konstytucji sejmu 1776 roku „Konwikcje w sprawach kryminalnych”, „Kwartalnik Historyczny" 103/ 3 (1996), s. 89-101.

${ }^{13}$ Por. J. B. Russell, Krótka historia czarownictwa, przeł. J. Rybski, Wydawnictwo Dolnośląskie, Wrocław 2003, s. 47-48. Omówienie stanu badań w polskiej literaturze przedmiotu zob. M. Pilaszek, dz. cyt., s. 17-46 (rozdział Jak opisać czary?).

${ }^{14}$ Szerzej na ten temat zob. R. Kieckhefer, Magia w średniowieczu, przeł. I. Kania, Universitas, Kraków 2000, s. 266.

${ }^{15}$ Dokładne statystyki podaje w swojej książce B. P. Levack, Polowanie..., s. 187-188.

${ }^{16}$ Zob. M. Pilaszek, dz. cyt., s. 30.

${ }^{17}$ Zob. H. Wiśniewska, Świat ptci żeńskiej baroku zaklęty w słowach, Wydawnictwo Uniwersytetu Marii Curie-Skłodowskiej, Lublin 2003, s. 242-243.

${ }^{18}$ Por. tamże. 
ówczesnych czarownic, uświadamiając, że ich domeną były nie tylko różnego rodzaju czary, ale i wróżbiarstwo ${ }^{19}$.

Problem płci nie może być w badaniach nad czarownictwem marginalizowany, dlatego warto przyjrzeć się z tej perspektywy najbardziej znanym interpretacjom tego fenomenu. Każda z nich zdawała się wyczerpująco tłumaczyć wszystkie fakty dotyczące wiary w czarownice i dawała nadzieję, że ich tajemnica została ostatecznie wyjaśniona. Prześledzenie dyskusji o czarownicach pomaga w zrozumieniu, co warunkowało funkcjonowanie tych postaci w kulturze dawnej oraz decydowało o sposobie ich percepcji.

Jedna z interpretacji mówi, że wiara w czarownice to wynik diabolizacji wierzeń i postaw występujących na piętnasto- i szesnastowiecznej wsi; za wiedźmę uznano wówczas kobietę zajmującą się czarami i czczącą, razem z innymi członkiniami sekty, diabła - źródło ich nadprzyrodzonych mocy. Pojawienie się czarownictwa jest więc wynikiem świadomej „współpracy” kobiet z szatanem. Do utrwalenia takiego wizerunku wiedźmy przyczynili się kaznodzieje, rozpowszechniający wśród niepiśmiennej ludności informacje zawarte w drukowanych traktatach demonologicznych, dobrze znane wśród duchownej i świeckiej elity ${ }^{20}$. Antyreligijny wymiar czarownictwa eksponowany jest w badaniach do dzisiaj ${ }^{21}$.

Koncepcja socjoekonomiczna widzi w czarownicy kozła ofiarnego (lub „koło ratunkowe" umożliwiające rozładowywanie napięć społecznych), obarczanego odpowiedzialnością za kryzysy religijne, destabilizację społeczną, wzrost cen i pogarszający się poziom życia, wojny, epidemie i niekorzystne zmiany klimatycz$n^{22}$. Idealną kandydatką do roli kozła była stara, nielubiana i samotna kobieta. Rzeczywiście, we wczesnonowożytnej Europie wiele kobiet ściganych za czary to staruszki pozbawione oparcia rodzinnego ${ }^{23}$. Oskarżano wdowy, stare panny, kobiety samotne, żyjące poza rodziną, nieprzystosowane do reguł obyczajowych i zwyczajowych grupy. Równie chętnie o czary posądzano zwykłe gospodynie domowe, przeciętne żony, matki, córki, a nawet małe dzieci² ${ }^{24}$. Mężczyźni najczęściej

${ }^{19}$ Wyraz „baba” funkcjonuje jako synonim wiedźmy już od XVI wieku. Por. Słownik prastowiański, red. F. Sławski, t. 1, Zakład Narodowy im. Ossolińskich, Wrocław 1974, s. 169.

${ }^{20}$ Zob. S. Salmonowicz, Procesy o czary w Polsce. Próba rozważań modelowych, w: Prawo wczoraj i dziś. Studia dedykowane profesor Katarzynie Sójce-Zielińskiej, red. G. Bałtruszajtys, Liber, Warszawa 2000, s. 315.

${ }^{21}$ Zob. M. Pilaszek, dz. cyt., s. 337.

${ }^{22}$ Polowania zbiegły się z dużymi anomaliami pogodowymi na terenie Europy, czyli tzw. mała epoką lodowcową. Por. W. Behringer, „, Kleine Eiszeit” und Frühe Neuzeit, w: Kulturelle Konsequenzen der „Kleinen Eiszeit”, red. W. Behringer, H. Lehmann, Ch. Pfister, Vandenhoeck \& Ruprecht, Göttingen 2005, s. 415-508.

${ }^{23}$ Zob. R. Kieckhefer, dz. cyt., s. 274.

${ }^{24}$ Zwraca na to uwagę w swych publikacjach J. Wijaczka. Zob. tenże, Procesy o czary w regionie świętokrzyskim w XVII-XVIII wieku, w: Z przeszłości regionu świętokrzyskiego od XVI do $X X$ wieku, red. tegoż, Agencja Reklamowo-Wydawnicza „Jard”, Kielce 2003; tenże, Procesy o czary w Prusach Książecych (Brandenburskich) w XVI-XVIII wieku, dz. cyt. 
byli powoływani przez kobiety dopiero w trakcie śledztwa. Nie można wykluczyć, że w niektórych przypadkach wykorzystywano posądzenia o uprawianie czarów do pozbycia się niewygodnych osób, rozwiązywania trudnych spraw rodzinnych i sąsiedzkich sporów, których nie dało się zakończyć w inny sposób.

Koncepcja etnologiczna upatruje źródeł zjawiska w starożytnej religii płodności opartej na kulcie Bogini Matki i rogatego boga Dianusa, która przetrwała do średniowiecza, kiedy to tradycja judeochrześcijańska ostatecznie wyparła z bóstwa pierwiastek żeński ${ }^{25}$. Jak do tej pory nie znaleziono jednak żadnych dowodów na istnienie wspomnianego kultu, dlatego koncepcja została ostatecznie odrzucona ${ }^{26}$.

Pojawiły się również głosy, że utożsamianie kobiet z czarownicami wynika z kompleksu Edypa i jakości dzieciństwa (diabeł jest substytutem ojca, stara brzydka czarownica - złej matki, młoda - zakazanym przedmiotem pożądania, uosabiającym męskie fantazje o nieokiełznanej kobiecej seksualności ${ }^{27}$. Feministki uznały czarownice za wytwór patriarchalnego świata (Betty Friedan, Mistyka kobiecości, 1965), a polowania - za symbol opresji kobiet i morderczej mizoginii ${ }^{28}$. Przywoływały w tym miejscu pisma św. Tomasza Akwinaty, św. Augustyna oraz Malleus maleficarum, który powtarzał i sankcjonował różne mity mizoginiczne: kobiety są słabsze moralnie i intelektualnie od mężczyzn, ale bardziej od nich zmysłowe, nie nadają się do sprawowania władzy, wchodzą w intymne kontakty z demonami, wywołują impotencję. Przyczynia się to do demonizowania przypisywanej niewiastom domowej przestrzeni (kuchnia, sypialnia) i codziennych kobiecych czynności (gotowanie, zajmowanie się dziećmi, odbieranie porodów). Co ciekawe, rodzimi pisarze zajmujący się demonologią (Benedykt Chmielowski, Jan Bohomolec) na ogół ignorowali w swoich utworach wątek mizoginiczny i marginalizowali rolę seksualności czarownic ${ }^{29}$.

${ }^{25}$ Książka Margaret Murray The Witch-Cult in Western Europe: A Study in Anthropology (Oxford 1921) i Merlin Stone When God Was a Woman (New York 1976). Kiedy ukazała się książka Murray (1921), wielu badaczy uznało, że tajemnica czarownic została ostatecznie wyjaśniona. $\mathrm{Na}$ ten temat zob. P. Lombardi, Filozof i czarownica. Rozum i świat magiczny, przeł. A. Dudzińska-Facca, Wydawnictwo Instytutu Filozofii i Socjologii PAN, Warszawa 2004, s. 15.

${ }^{26}$ Przegląd wystąpień krytycznych wobec książki Murray zawiera publikacja A. Macfarlane, Murray's Theory: Exposition and Comment, w: Witchcraft and Sorcery: Selected Readings, red. M. Marwick, Penguin Books, London 1970, s. 233-234.

${ }^{27}$ Zob. L. Roper, Oedipus and the Devil: Witchcraft, Religion, and Sexuality in Early Modern Europe, Routledge 1994.

${ }^{28}$ O mizoginizmie zob. F. Beer, Kobiety i doświadczenia mistyczne w Średniowieczu, przeł. A. Branny, Znak, Kraków 1996, s. 8-13; D. Gilmore, dz. cyt., s. 16-17. Mizoginia miała odległe tradycje - składały się nań literatura antyczna, religia hebrajska i dualizm potępiający cielesność.

${ }^{29}$ Zob. B. Chmielowski, Nowe Ateny albo Akademia wszelkiey scyencyi petna, na różne tytuty iak na Classes podzielona, Mądrym dla memoryału, Idiotom dla Nauki, Politykom dla Praktyki, Melancholikom dla rozrywki erygowana, wybór i oprac. tekstu M. i J. J. Lipscy, Wydawnictwo Literackie, Kraków 1968, s. 85-94; 120-130; 134-136. J. Bohomolec, Diabet w swojej postaci z okazji pytania „Jeśli sq upiory” ukazany. Część pierwsza, Warszawa 1772, s. 128-139. 
Choć przekonanie, że mężczyźni nie uprawiali magii jest całkowicie błędne, od starożytności przypisywano ją głównie kobietom, zwłaszcza czary szkodliwe ${ }^{30}$. W starożytnej literaturze odnajdziemy wiele określeń odnoszących się do kobiet $\mathrm{w}$ tej roli: maga, venifica, saga, malefica, anus (starucha) $)^{31}$. W antyku magią parały się często cudzoziemki - Greczynki, zwłaszcza Tesalki, oraz kobiety Wschodu. Prawdopodobnie uprawiały one powszechnie akceptowane zawody, pracując jako karczmarki, akuszerki i handlarki olejkami wzmagającymi atrakcyjność seksual$n a^{32}$. Wydaje się, że mamy tu do czynienia z przejawem demonizowania określonych grup etnicznych, postrzeganych jako obce czy egzotyczne ${ }^{33}$.

Zrodziła się również myśl, że eksterminacja czarownic wynikała z chęci wyeliminowania zielarek i akuszerek z rynku usług medycznych w wyniku pojawienia się około dwunastego wieku lekarzy $\mathrm{z}$ wykształceniem uniwersyteckim ${ }^{34}$. Absolwenci studiów medycznych, kierowani zazdrością o klientów, mogli dążyć do instrumentalizacji procesów. Akuszerki pomawiano o usuwanie ciąż, mordowanie dzieci i oddawanie ich diabłu w czasie sabatu. Zdarzało się, że położne same dawały pretekst oskarżycielom, decydując się na podejrzane działania w dobrej wierze, na przykład dostarczając klientowi tłuszcz poronionego płodu, mający leczyć trą $\mathrm{d}^{35}$. W czasach, kiedy brakowało fachowej opieki medycznej, takie prośby zapewne pojawiały się stosunkowo często. Niewykluczone, że niektóre oskarżenia wysuwane przeciw kobietom obecnym przy porodzie były wynikiem depresji poporodowej - matki obwiniały położne nie tylko o śmierć dzieci, ale i o rzucenie na nie czaru, który pozbawiał je miłości do noworodka.

Powinowactwo medycyny i czarów ujawnia się także w przekonaniu, że domniemane czarownice to kobiety cierpiące na schorzenia psychiczne, typowe dla ich płci ${ }^{36}$. Objawy rzekomego czarownictwa wiąże się z chorobami nerwowymi, takimi jak histeria czy kleptomania ${ }^{37}$. Nie jest to pomysł nowy, czego dowodem są dyskusje, jakie toczyły się na Zachodzie w okresie polowań. Na gruncie polskim problem ten pojawia się w rozprawie oświeconego jezuity Jana Bohomolca

${ }^{30}$ Opisywane przez Apulejusza w Metamorfozach albo Złotym ośle czarownice z Tesalii cieszyły się szczególnie złą sławą i często oskarżane były o czyny wykraczające poza obowiązujące normy etyczne, takie jak porwania i mordowanie dzieci oraz łamanie uświęconego tabu (poprzez kanibalizm czy nekrofilię). Zob. A. Wypustek, dz. cyt., s. 43.

${ }^{31}$ Tamże, s. 301.

${ }^{32}$ Być może mamy tu do czynienia wyłącznie ze stereotypami i fikcją. A. Wypustek, dz. cyt., s. 301. Największe możliwości do praktykowania magii i pobierania za to wynagrodzenia w przedchrześcijańskim świecie mieli kapłani. Tamże, s. 303-307.

${ }^{33} \mathrm{~W}$ późniejszym okresie na tej samej zasadzie przypisywano czary Żydom oraz Cyganom.

${ }^{34}$ Zob. R. Kieckhefer, dz. cyt., s. 99.

35 Tamże, s. 102.

${ }^{36}$ Zob. J. Bohomolec, dz. cyt., s. 130-131. Por. M. Skrzypek, Oświeceniowa kategoria przesadów (z Ciemnogrodem Potockiego w tle), „Studia Wilanowskie” 19 (2012), s. 29-30.

${ }^{37}$ Por. B. P. Levack, dz. cyt., s. 211. Levack tłumaczy nienaturalne zachowania posądzanych o czary kobiet naturalnymi zmianami starczymi. 
Diabeł w swojej postaci (1772). W pierwszej części książki, na marginesie rozważań o sabatach, wspomina on o przypadkach samooskarżeń kobiet ${ }^{38}$. Autor dowodzi, że są one następstwem kilku czynników. Do nocnych lotów przyznają się zazwyczaj:

niewiasty, to jest skłonne z natury do melancholii i częstokroć podległe hipochondrii, którą w nich nazywają lekarze histericus morbus albo macicowa choroba. Jakiego zaś stanu? Nigdy prawie z godnych i majętnych, ale niewiasty proste, ubogie, w nędzy żyjące, to jest tymi karmiące się potrawami, tym podlegające niewygodom, które bez wrodzonych skłonności same przez się umysłu choroby sprowadzają i pomnażają w ludziach ułożenia lubo ciała najzdrowszego $0^{39}$.

Histerię, określaną też mianem duszności macicznej, wyobrażano sobie jako efekt oddziaływania podrażnionej i nieusatysfakcjonowanej seksualnie macicy, która przemieszczała się wewnątrz kobiecego ciała i powodowała przez swe ruchy zaburzenia innych organów wewnętrznych ${ }^{40}$. Macica porównywana była do zwierzęcia, z czego wyciągano wnioski, że kobieta, hodując w sobie istotę nieposiadająca duszy, nie jest równa mężczyźnie, lecz od niego gorsza. Choroba macicy objawiała się nagle i niespodziewanie dziwacznymi stanami psychicznymi, zbliżonymi z zachowaniem czarownic lub opętanych ${ }^{41}$.

Niezależnie od tego, która z przywołanych koncepcji czarownictwa najbardziej zbliża się do prawdy, nie sposób odnieść wrażenia, że rola i funkcja postaci magicznej w literaturze i sztukach plastycznych warunkowana jest jej płcią. Artystyczne kreacje czarownic w piśmiennictwie dawnym wykazują daleko idące podobieństwo i obejmują takie elementy jak utrzymany w poetyce brzydoty wygląd, wszelkie anomalie fizyczne, nieakceptowane społecznie zachowania (pakt $\mathrm{z}$ diabłem, podejmowanie z nim kontaktów cielesnych, nocny lot, udział w sabacie, uprawianie szkodliwych czarów) i charakterystyczny typ przypisanej im przestrzeni (graniczna, funeralna, loco secreto). Z czasem katalog cech czarownicy wzbogaca się o nowe elementy, takie jak posiadanie znamienia, pełniącego funkcję dodatkowego sutka, służącego do karmienia familiariuszy ${ }^{42}$, udział w rozprzestrzenianiu się chorób zakaźnych, zdolność do transformacji, tworzenie

${ }^{38}$ Jezuita odwołuje się tu do poglądów Johanna Wiera, który uznał, że diabeł wykorzystuje chore umysły nieszczęsnych kobiet. Wyobraźnia każe im twierdzić, że dopuściły się czegoś, czego nie popełniły. E. Trillat, Historia histerii, przeł. Z. Podgórska-Klawe i E. Jamrozik, Zakład Narodowy im. Ossolińskich, Wrocław 1993, s. 37. Por. M. Skrzypek, dz. cyt., s. 29.

${ }^{39}$ J. Bohomolec, dz. cyt., s. 130-131.

${ }^{40}$ E. Trillat, dz. cyt., s. 10-11.

${ }^{41}$ Tamże, s. 37.

${ }^{42}$ P. Rutkowski, dz. cyt., s. 250-260. 
upiorów czy wilkołaków ${ }^{43}$. Główną i najważniejszą cechą czarownic nie jest jednak ich brzydota cielesna, ale inność i robienie wszystkiego na opak, odwrotnie do powszechnie przyjętego porządku. U schyłku epoki wczesnonowożytnej wiele literackich czarownic posiada strukturę hybrydalną, łącząc w sobie cechy istot demonicznych i półdemonicznych (wampira, sukuba czy wręcz diabła). Bohaterki żartobliwej ody Franciszka Dionizego Kniaźnina Babia góra. Do Pawta Czenpinskiego gdy objeżdzal góry krakowskie (wyd. 1787) latają na łopatach i piją krew młodych mężczyzn ${ }^{44}$. Pragnienie krwi młodzieńców - metafora chęci miłosnego zbliżenia i wyssania z partnera sił witalnych - wskazuje na ich archetypiczną lubieżność. Afryna, demoniczna bohaterka anonimowego poematu heroikomicznego Magnetyzm zwierzęcy (1818) na oczach czytelnika przechodzi swoistą metamorfozę: aby uwieść głównego bohatera utworu, z brzydkiej wiedźmy przeistacza się w piękną młodą kobietę ${ }^{45}$. Stereotypowy wygląd pełni więc w poemacie funkcję okazjonalnego kostiumu, nakładanego w zależności od potrzeb.

Czarownice ukazywane są zwykle jako kobiety konfliktowe i wulgarne, żebraczki, najczęściej stare, zgodnie z przeświadczeniem, że podeszły wiek gwarantuje mądrość magiczną ${ }^{46}$. Ujawnia się tu przekonanie, że skłonności do czarów wiążą się z biologicznymi funkcjami kobiety. Sprzyja im menopauza, zanik miesiączkowania i nieutrzymywanie kontaktów seksualnych, powodujące wyschnięcie macicy i wspomnianą wcześniej histerię. Pisarze na ogół nie wyposażają czarownic w magiczną księgę, bo reprezentują one magię niską, niewymagającą teoretycznego przygotowania ${ }^{47}$. W galerii czarownic poza nielicznymi wyjątkami ${ }^{48}$ nie ma odpowiedników uczonych magów czy astrologów, zajmujących pozycję nadwornych mędrców i doradców panujących.

Status społeczny czarownicy jest stosunkowo niski. Kreacje literackie obejmują zwykle ludowe wiedźmy, pomagające innym kobietom zajść w ciążę, zdobyć lub odzyskać męża, osłonić sekrety przyszłości. Klientkami czarownic są również kobiety niepotrafiące rozwiązać problemów dostępnymi legalnie środkami. Opis czynności magicznych staje się najczęściej pretekstem do uświadomienia czytelnikowi poważnych problemów etycznych związanych z próbą zdominowania drugiej osoby przy pomocy magii. Przykłady takiego ujęcia problemu odnaj-

${ }^{43}$ Por. B. Baranowski, W kręgu upiorów i wilkołaków, Wydawnictwo Łódzkie, Łódź 1971, s. 149.

${ }^{44}$ F. D. Kniaźnin, Babia góra. Do Pawła Czenpinskiego gdy objeżdżał góry krakowskie, w: Z. Libera, Poezja polska XVIII wieku, Czytelnik, Warszawa 1976, s. 353-356.

${ }^{45}$ Magnetyzm zwierzecy, „Tygodnik Wileński”, t. VI, 1818, s. 80-86.

${ }^{46}$ J.B. Russell, dz. cyt., s. 133.

${ }^{47}$ Magię niską wiązano z kobietami już w starożytności. Polowania na czarownice utrwaliły przekonanie, że oskarżone kobiety czerpały moce nadprzyrodzone $\mathrm{z}$ diabła, a nie z ksiąg i studiów nad magią.

${ }^{48} \mathrm{~W}$ literaturze polskiej do wyjątków należy czarownica z powieści Juliana Ursyna Niemcewicza Jan z Tęczyna (1825). 
dziemy w staropolskich sielankach (Czary Szymona Szymanowskiego i Odczary na Simonidesowe Czary Jana Gawińskiego) oraz w pseudohistorycznej powieści Astolda Anny Mostowskiej (1807). Ciekawą kreację czarownicy zawiera powieść Jan z Tęczyna Juliana Ursyna Niemcewicza. Kobieta to pomaga zajść królowej Barbarze Radziwiłłównie w upragnioną ciążę. Z punktu widzenia obserwatora, obawiającego się czarów, używane do nich rekwizyty nadają czynnościom znachorki diabelski charakter ${ }^{49}$. Nieetyczne działanie przywołanych wyżej postaci wynika z faktu, że korzystają one z pomocy sił piekielnych albo wierzą w możliwość współpracy z diabłem.

Wczesnonowożytna czarownica pojawia się najpierw w traktatach i bullach, a następnie w ikonografii (drzeworyty Jana Ziarnki, ilustracje do publikowanych wówczas rozpraw demonologicznych; obrazy Albrechta Dürera, Hieronima Boscha, Hansa Baldunga Griena) i literaturze pięknej, stając się z czasem samodzielnym motywem a nawet centralną postacią świata przedstawionego. Duża frekwencja i różnorodność ujęć motywu w dawnej sztuce pokazuje skalę zainteresowania czarownictwem w społeczeństwie i jego przekonanie o dużej wadze problemu. Szczególny niepokój budziła wśród ludzi magia pogodowa. Kiedy uświadomimy sobie, że egzystencja człowieka była w przeszłości o wiele bardziej uzależniona od pogody i pór roku niż obecnie, stanie się jasne, że możliwość wpływania czarownicy na naturę odbierano jako realne zagrożenie kosmicznego ładu.

W rzeczywistości pozaliterackiej nie wszystkie oskarżone spełniały narzucone przez stereotyp kryteria. Choć w rzeczywistości o czary posądzano zwykle zamężne chłopki i mieszczanki, niewyróżniające się z otoczenia, w tekstach literackich i dziełach plastycznych eksponowano te elementy stereotypu, które najbardziej przemawiały do wyobraźni tłumu (brzydota, lot, sabat, magia pogodowa, pakt $\mathrm{z}$ diabłem, akt seksualny z demonem, powodowanie impotencji). Utrwalony stereotyp postaci (czarownica to złośliwa, stara i samotna kobieta) i sytuacji (nieurodzaj i choroba to skutki działania czarownicy), każe identyfikować ludziom wybrane elementy wyglądu i zachowania kobiet z przyswojonym w podświadomości wzorcem. O jego popularności w osiemnastym wieku świadczy reakcja bohatera poematu heroikomicznego Ignacego Krasickiego Myszeida (1775), który ujrzawszy „dziwotwora”, „babę przestarzałą” ,poznał z postaci zaraz czarownicą"50. Kreacja Krasickiego to przykład przełamywania konwencji modelowania wizerunku czarownicy przy użyciu przerysowanych środków poetyckiej ekspresji.

${ }^{49}$ Lęk budzi sam wygląd kobiety, będący już częścią stereotypu. To stara, jak na owe czasy, niewiasta ,już lat przeszło czterdzieści mająca, postać jej wysoka, płeć śniada, najmniejszym niezażywiona rumieńcem, lecz niezmiernie duże czarne oczy, również czarne brwi stykające się prawie z sobą dawały twarzy jej wyraz, który nieprędko ścierał się z pamięci tych, którzy raz na nią patrzali”. J. U. Niemcewicz, Jan z Tęczyna, Universitas, Kraków 2003, s. 81.

${ }^{50}$ I. Krasicki, Myszeida, w: tegoż, Pisma poetyckie, oprac. Z. Goliński, t. 1, Państwowy Instytut Wydawniczy, Warszawa 1976, s. 64. 
Funkcjonujący w literaturze dawnej schemat opisu postaci czarownic eksponuje te same elementy, choć w różnym stopniu, kolejności czy hierarchii. Autorzy powstających wówczas utworów nawiązują zazwyczaj do dwóch skonwencjonalizowanych, biegunowo różnych wzorców (stara lubieżna baba i młoda, piękna uwodzicielka). Baby posiadają stereotypowy dla zbiorowych wyobrażeń wygląd i akcesoria (miotły służące jako środek transportu; różdżki, którymi kreślą cyrkuł), wykonują przypisywane wiedźmie czynności (izolują się od ludzi, uczestniczą w sabatach, przemieszczają się w powietrzu, korzystają z pomocy demonów). Uwodzicielki kuszą mężczyzn cielesnością, baby wywołują obrzydzenie. W obu przypadkach eksponuje się fizyczność czarownic.

Archiwa pokazują, że w praktyce sądowniczej nie było jednego obowiązującego schematu, nie palono wyłącznie starych kobiet, akuszerek, wdów czy żebraczek, a kobiety uczestniczyły w procesach innych kobiet jako oskarżycielki i pomocniczki sędziów. Wśród ofiar znajdziemy także zamężne gospodynie domowe w wieku produkcyjnym. Są jednak czynniki, które predestynują określone grupy społeczne do prześladowań (nieustalona pozycja społeczna i rodzinna, odbiegający od obowiązujących norm wygląd lub zachowanie, inność i robienie wszystkiego na opak, odwrotnie do powszechnie przyjętego porządku), ponadto zachowania kobiet częściej niż mężczyzn podlegały seksualizacji.

Wbrew krążącym opiniom, nie wszystkie czarownice były powszechnie znienawidzone, przynajmniej dopóki były potrzebne lokalnej społeczności, pomagały ludziom, zapewniały im pomyślność i chroniły przed innymi czarami. Jeśli jednak czary nie powiodły się albo ktoś poczuł się ich ofiarą, podejrzenie natychmiast padało na czarownice. $\mathrm{Z}$ działalnością wiedźm wiązał brak potomstwa Jan Chryzostom Pasek, dając temu wyraz w swoich pamiętnikach ${ }^{51}$.

Na wizerunek czarownicy wpłynęły elementy przedchrześcijańskie, zarówno tradycje antyczne, jak i rodzimy folklor. W literaturze antycznej odnajdziemy charakterystyczne cechy topicznego wizerunku czarownic, na przykład przekonanie, że do czarów predestynuje kobiety ich natura ${ }^{52}$. W swoich działaniach posuwają się do ostateczności; jeśli nie praktykują czarów osobiście, to zwracają się o pomoc do specjalistów. W rzeczywistości to mężczyźni częściej korzystali z ich porad ${ }^{53}$. Archetyp wiedźmy uosabiają: morderczyni własnych dzieci Medea, czarodziejka Kirke, Horacjańska Kanidia oraz Erichto, nekromantka z Wojny domowej Marka Anneusza Lukana. O pokrewieństwie z wczesnonowożytną czarownicą decydują wybrane epizody z ich biografii, ujawniające ich okrucieństwo, lubieżność czy nieposkromioną namiętność.

${ }^{51}$ J.C. Pasek, Pamiętniki, oprac. R. Pollak, Państwowy Instytut Wydawniczy, Warszawa 1971, s. 287.

${ }^{52}$ Zob. T. Sapota, Magia i religia w twórczości Lucjusza Apulejusza z Madaury, Zakład Wydawniczy Nomos, Kraków 2001, s. 189-190, 194.

${ }^{53}$ Por. A. Wypustek, dz. cyt., s. 278. 
Według autora Młota na czarownice, słabsze moralnie od mężczyzn kobiety łatwiej ulegają podszeptom szatana i są bardziej podatne na działania ujmowane jako kuszenie. Dlatego wszystkie czary miały brać swój początek z cielesnej żądzy. Inkwizytor francuski Jean Bodin poszedł jeszcze dalej w ocenie natury kobiet, uznając za główną przyczynę czarownictwa ich „zwierzęcą zachłanność” i lubieżność ${ }^{4}$. Historia motywu cyrografu pokazuje, że szatan kusił obie płcie, ale $\mathrm{z}$ różnych powodów i innymi środkami ${ }^{55}$. Kochanice diabła oddawały się mu w dosłownym tego słowa znaczeniu, dla rozpusty lub innych doraźnych korzyści ${ }^{56}$. Mężczyźni, nieobwiniani w takim samym stopniu jak kobiety o dewiacje seksualne, zawierali pakty z powodu utraty wiary, pragnienia zdobycia sławy czy chęci rozwikłania tajemnicy wszechświata ${ }^{57}$. Potwierdzają to literackie kreacje legendarnych magów (mistrz Twardowski, Doktor Faust). Czarnoksiężnicy to uczeni, którzy drogą studiów lub eksperymentów pragną dociec najgłębszych tajników natury wszechświata (Jamedyk Blud z utworu Zdobycie Kijowa Tymona Zaborowskiego ${ }^{58}$ ), oddani panującym patrioci (turecki czarownik Omar z Wojny chocimskiej Ignacego Krasickiego), prawowici władcy, zatracający się w wiedzy tajemnej (potężny mag Prospero z Burzy Szekspira ${ }^{59}$ ).

Przytoczone powyżej przykłady zdają się potwierdzać, że aspekt płci jest istotny dla problemu czarownictwa i wpływa na utrwalony w literaturze dawnej wizerunek czarownicy. Nie możemy jednak zapominać o stawianych przez badaczy pytaniach i nasuwających się wątpliwościach ${ }^{60}$. Czy relacje między płciami ewoluowały w XVIII wieku tak bardzo, aby mogły wyjaśnić zmianę stosunku społeczeństwa do czarownicy i w konsekwencji wygaszanie procesów o czary? Oświecenie nazywane bywa nie tylko wiekiem rozumu i gustu, ale i epoką dominacji kobiet. Według niektórych badaczy w Europie kiełkuje wówczas nieśmiało femi-

${ }^{54}$ B. P. Levack, dz. cyt., s. 71-72.

${ }^{55}$ Zob. W. Brojer, Diabeł w wyobraźni średniowiecznej. Trzynastowieczne exempla kaznodziejskie, Wydawnictwo Uniwersytetu Wrocławskiego, Wrocław 2003, s. 511. Por. tenże, Pakt z diabłem w średniowieczu, jeden motyw - dwa modele, w: Ludzie, Kościót, wierzenia. Studia z dziejów kultury i społeczeństwa Europy Środkowej (średniowiecze - wczesna epoka nowożytna), red. W. Iwańczak i S. K. Kuczyński, Wydawnictwo DiG, Warszawa 2001, s. 347-371.

${ }^{56}$ Literatura demonologiczna podaje przykłady tego typu związków, nierzadko obdarzonych potomstwem, wyjaśniając szczegółowo, w jaki sposób dochodzi do zapłodnienia. A. M. di Nola, Diabet, tłum. I. Kania, Universitas, Kraków 2001, s. 237-242. Postać żonatego lub chcącego się ożenić diabła pojawia się dość często w opowieściach ludowych. Zob. Słownik folkloru polskiego, red. J. Krzyżanowski, Wiedza Powszechna, Warszawa 1965, s. 81-83, hasło: Diabet w literaturze ludowej.

${ }^{57}$ Zob. J. Wijaczka, Procesy o czary w Polsce w epoce nowożytnej, „Kwartalnik Historyczny" 3, 2009, s. 120.

${ }^{58}$ Zob. J. Jupiter, O eposie Tymona Zaborowskiego „Zdobycie Kijowa” i jego redakcjach, „Pamiętnik Literacki” 1932, z. 29, s. 363-366.

${ }^{59}$ Zob. S. Greenblatt, Shakespeare. Stwarzanie świata, przeł. B. Kopeć-Umiastowska, Wydawnictwo W. A.B., Warszawa 2007, s. 359-363.

${ }^{60}$ Por. M. Pilaszek, dz. cyt., s. 99. 
nizm, pojmowany jako ruch intelektualny o zdefiniowanych zasadach i celach ${ }^{61}$. Ze względu na ideę równości płci stanowi on integralny element epoki, której celem miało być wyzwolenie ze wszystkich przesądów hamujących postęp ludzkości. Podejmowano wtedy próby przełamywania uprzedzeń związanych z płcią. Podano w wątpliwość wiele uznanych poglądów na rodzinę, relacje między płciami i na naturę. $Z$ drugiej jednak strony nie milkną głosy, wedle których mizoginizm filozofii miał w myśli oświecenia wręcz swoją kulminację a kategoria kobiecości stała się negatywnym odniesieniem do wszystkiego, co męskie ${ }^{62}$. Wielowiekowa tradycja, uznająca kobietę za istotę słabszą i mniej rozumną od mężczyzny, pozwalała również w „wieku świateł” stawiać płeć słabszą niżej od mężczyzn.

Wydaje się, że do zaniku „szaleństwa czarownic” w większym stopniu niż emancypacja kobiet przyczyniły się inne czynniki, na przykład narastające wątpliwości sędziów co do winy oskarżanych kobiet. Na ustanie procesów wpłynęła również moda na sceptycyzm w warstwach wyższych i ich strach przed ośmieszeniem się na skutek posądzenia o zabobonność. Fundamenty, na których wznosi się koncepcja czarownictwa, skutecznie podkupuje też pozbawienie złego ducha przypisywanych mu mocy ${ }^{63}$. Potęga czarownic brała się bowiem z ich przymierza z diabłem.

\section{Bibliografia}

\section{Podmiotowa}

Bohomolec Jan, Diabet w swojej postaci z okazji pytania „,Jeśli sq upiory” ukazany. Część pierwsza, Warszawa 1772.

Chmielowski Benedykt, Nowe Ateny albo Akademia wszelkiey scyencyi pełna, na różne tytuty iak na Classes podzielona, Mądrym dla Memoryatu, Idiotom dla Nauki, Politykom dla Praktyki, Melancholikom dla rozrywki erygowana, wybór i oprac. tekstu M. i J. J. Lipscy, Wydawnictwo Literackie, Kraków 1968.

Kniaźnin Franciszek Dionizy, Babia góra. Do Pawła Czenpinskiego gdy objeżḋał góry krakowskie, w: Zbigniew Libera, Poezja polska XVIII wieku, Warszawa 1976, s. 353-356.

Krasicki Ignacy, Myszeida, w: tegoż, Pisma poetyckie, oprac. Z. Goliński, t. 1, Państwowy Instytut Wydawniczy, Warszawa 1976, s. 41-90.

Magnetyzm zwierzęcy, ,Tygodnik Wileński”, t. VI, 1818, s. 80-86.

Niemcewicz Julian Ursyn, Jan z Tęczyna, Universitas, Kraków 2003.

Pasek Jan Chryzostom, Pamiętniki, oprac. R. Pollak, Państwowy Instytut Wydawniczy, Warszawa 1971.

Collin de Plancy Jacques, Czarownicy, w: Słownik wiedzy tajemnej, wybór i przekład Michał Karpowicz, Oficyna Wydawnicza Polczek, Warszawa-Kraków 1993, s. 38-43.

Zaborowski Tymon, Zdobycie Kijowa, Universitas, Kraków 2003.

${ }^{61}$ Zob. J. Bator, Pożegnanie oświeceniowej metanarracji?, w: tejże, Feminizm, postmodernizm, psychoanaliza. Filozoficzne dylematy feministek ,drugiej fali”, Wydawnictwo Słowo/Obraz Terytoria, Gdańsk 2001, s. 29.

${ }^{62}$ Zob. taż, Feminizm wielkich opowieści, w: tejże, Feminizm, postmodernizm..., s. 115.

${ }^{63}$ Szerzej na ten temat zob. D. Kowalewska, dz. cyt., s. 85-91. 


\section{Przedmiotowa}

Baranowski Bohdan, O hultajach, wiedźmach $i$ wszetecznicach, Wydawnictwo Łódzkie, Łódź 1963.

Baranowski Bohdan, Pożegnanie z diabłem i czarownica, Wydawnictwo Łódzkie, Łódź 1965.

Baranowski Bohdan, Procesy czarownic w Polsce XVII i XVIII w., Łódzkie Towarzystwo Naukowe, Łódź 1952.

Bator Joanna, Feminizm, postmodernizm, psychoanaliza. Filozoficzne dylematy feministek „drugiej fali", Wydawnictwo Słowo/Obraz Terytoria, Gdańsk 2001.

Bechtel Guy, Cztery kobiety Boga: ladacznica, czarownica, święta, głupia gęś, przeł. Katarzyna Pachniak, Wydawnictwo Akademickie Dialog, Warszawa 2001.

Beer Frances, Kobiety i doświadczenia mistyczne w Średniowieczu, przeł. Andrzej Branny, Wydawnictwo Znak, Kraków 1996.

Brojer Wojciech, Diabeł w wyobraźni średniowiecznej. Trzynastowieczne exempla kaznodziejskie, Wydawnictwo Uniwersytetu Wrocławskiego, Wrocław 2003.

Czary, alchemia, opętanie w kulturze na przestrzeni stuleci. Studia przypadków, red. J. Pietrzak-Thebault i Ł. Cybulski, Wydawnictwo Uniwersytetu Stefana Kardynała Wyszyńskiego, Warszawa 2015.

Gilmore David, Mizoginia, czyli męska choroba, przeł. Janusz Margański, Wydawnictwo Literackie, Kraków 2003.

Greenblatt Stephen, Shakespeare. Stwarzanie świata, przeł. Barbara Kopeć-Umiastowska, Wydawnictwo W. A.B., Warszawa 2007.

Jupiter J., O eposie Tymona Zaborowskiego „Zdobycie Kijowa” i jego redakcjach, „Pamiętnik Literacki" 1932, z. 29, s. 349-390.

Kieckhefer Richard, Magia w średniowieczu, przeł. Ireneusz Kania, Universitas, Kraków 2000.

Kopaliński Władysław, Encyklopedia „,drugiej płci”: wszystko o kobietach, Oficyna Wydawnicza Rytm, Warszawa 2006.

Kowalewska Danuta, Magia i astrologia w literaturze polskiego oświecenia, Wydawnictwo Naukowe Uniwersytetu Mikołaja Kopernika, Toruń 2009.

Levak Brian, Polowanie na czarownice w Europie wczesnonowożytnej, przeł. Edward Rutkowski, $\mathrm{z}$ dodatkiem Katalogu magii Mnicha Rudolfa zabytku z XIII w. w przekładzie Edwarda Karwota, Zakład Narodowy im. Ossolińskich, Wrocław 2009.

Lombardi Paolo, Filozof i czarownica. Rozum i świat magiczny, przeł. Anna Dudzińska-Facca, Wydawnictwo Instytutu Filozofii i Socjologii PAN, Warszawa 2004.

Ludzie, Kościót, wierzenia. Studia z dziejów kultury i społeczeństwa Europy Środkowej (średniowiecze - wczesna epoka nowożytna), red. W. Iwańczak i S. K. Kuczyński, Wydawnictwo DiG, Warszawa 2001.

Marcińczak Bartosz, ,, Między łacnowiernością i niewiernościa”. Diabeł magia i czary w „Nowych Atenach" $i$,Diable w swojej postaci”, Wydawnictwo DiG, Warszawa 2014.

Michalski Jerzy, Jeszcze o konstytucji sejmu 1776 roku „Konwikcje w sprawach kryminalnych”, „Kwartalnik Historyczny” 103/ 3 (1996), s. 89-101.

Nola Alfonso Maria di, Diabet. O formach, historii i kolejach losu Szatana, a także o jego powszechnej a złowrogiej obecności wśród wszystkich ludów, od czasów starożytnych aż po teraźniejszość, tłum. Ireneusz Kania, Universitas, Kraków 2001.

Pilaszek Małgorzata, Procesy o czary w Polsce w wiekach XV-XVIII, Universitas, Kraków 2008.

Roper Lyndal, Oedipus and the Devil: Witchcraft, Religion, and Sexuality in Early Modern Europe, Routledge 1994.

Russell Jeffrey B., Krótka historia czarownictwa, przeł. Jarosław Rybski, Wydawnictwo Dolnośląskie, Wrocław 2003.

Rutkowski Paweł, Kot czarownicy. Demon osobisty w Anglii wczesnonowożytnej, Universitas, Kraków 2012. 
Salmonowicz Stanisław, Procesy o czary w Polsce. Próba rozważań modelowych, w: Prawo wczoraj i dziś. Studia dedykowane profesor Katarzynie Sójce-Zielińskiej, red. G. Bałtruszajtys, Liber, Warszawa 2000, s. 303-321.

Sapota Tomasz, Magia i religia w twórczości Lucjusza Apulejusza z Madaury, Zakład Wydawniczy Nomos, Kraków 2001.

Segl Peter, Heinrich Institoris. Persönlichkeit und literarisches Werk, w: Der Hexenhammer. Entstehung und Umfeld des Malleus maleficarum von 1487, red. P. Segl, Böhlau, Köln-Wien 1988, s. 103-126.

Skrzypek Marian, Oświeceniowa kategoria przesadów (z Ciemnogrodem Potockiego w tle), „Studia Wilanowskie" 2012, z. 19.

Słownik prasłowiański, red. Franciszek Sławski, t. 1, Zakład Narodowy im. Ossolińskich, Wrocław 1974.

Tazbir Janusz, Wawrzeniecki i Żagiell jako twórcy falsyfikatów, „Nauka” 3 (2006), s. 45-53.

Trillat Etienne, Historia histerii, przeł. Zofia Podgórska-Klawe i Elżbieta Jamrozik, Zakład Narodowy im. Ossolińskich, Wrocław 1993.

Wijaczka Jacek, Magia i czary. Polowanie na czarownice i czarowników w Prusach Ksiązęcych w czasach wczesnonowożytnych, Wydawnictwo Adam Marszałek, Torun 2008.

Wijaczka Jacek, Procesy o czary w Polsce w epoce nowożytnej, „Kwartalnik Historyczny” 3, 2009.

Wijaczka Jacek, Procesy o czary w Prusach Ksiażęcych (Brandenburskich) w XVI-XVIII wieku, Wydawnictwo Naukowe Uniwersytetu Mikołaja Kopernika, Torun 2007.

Wiśniewska Halina, Świat ptci żeńskiej baroku zaklęty w słowach, Wydawnictwo Uniwersytetu Marii Curie-Skłodowskiej, Lublin 2003.

Wyporska Wanda, Witchcraft in Early Modern Poland, 1500-1800, Palgrave Macmillan, Basingstoke 2013.

Wypustek Andrzej, Magia antyczna, Zakład Narodowy im. Ossolińskich, Wrocław 2001.

Zjawiska magiczno-demoniczne na terenie dawnych ziem pruskich na tle porównawczym, red. K. Grążawski i J. Gancewski, Wydawnictwo Uniwersytetu Warmińsko-Mazurskiego, Olsztyn 2015.

Danuta Kowalewska

\section{Witch in Polish Enlightenment Literature. Stereotype and Sex}

\section{(Summary)}

The article focuses on the image of witches in the iconography, literature, and imagination of the inhabitants of Early Modern Europe (from the late Middle Ages to the Enlightenment). It endeavours to explain whether the role and function of magical figures in Early Modern literature is conditioned by gender and by the conviction that magic is related to the biological functions of women. I will also attempt to determine how the stereotype of the witch emerged and whether its function in literature was influenced by the changed relations between the sexes in the $18^{\text {th }}$ century. Although the main area of interest are works in Polish, numerous references to foreign literature are also made.

Keywords: witchcraft; witch; magic; Enlightenment; woman; misogyny

Słowa kluczowe: czarownictwo; czarownica; magia; oświecenie; kobieta; mizoginizm 